\title{
Differential Roles of Two Leptin Gene Paralogues on Food Intake and Hepatic Metabolism Regulation in Mandarin Fish
}

\author{
Xiao-Chen Yuan ${ }^{1,2}$, Xu-Fang Liang ${ }^{1,2 *}$, Wen-Jing Cai ${ }^{1,2}$, Ai-Xuan $L^{1,2}{ }^{1,}$ Dong Huang ${ }^{1,2}$ and \\ Shan $\mathrm{He}^{1,2}$
}

${ }^{1}$ College of Fisheries, Chinese Perch Research Center, Huazhong Agricultural University, Wuhan, China, ${ }^{2}$ Key Lab of Freshwater Animal Breeding, Ministry of Agriculture and Rural Affair/ Hubei Engineering Technology Research Center for Fish Breeding and Healthy Aquaculture, Wuhan, China

\section{OPEN ACCESS}

Edited by:

Oliana Carnevali,

Marche Polytechnic University, Italy

Reviewed by:

Marta Conde-Sieira,

University of Vigo, Spain

Yong Zhang,

Sun Yat-Sen University, China

${ }^{*}$ Correspondence:

Xu-Fang Liang

xufang_liang@hotmail.com

Specialty section:

This article was submitted to Experimental Endocrinology,

a section of the journal

Frontiers in Endocrinology

Received: 22 January 2020

Accepted: 03 June 2020

Published: 14 August 2020

Citation:

Yuan X-C, Liang X-F, Cai W-J, Li A-X, Huang $D$ and He S (2020) Differential Roles of Two Leptin Gene Paralogues on Food Intake and Hepatic Metabolism Regulation in Mandarin Fish. Front. Endocrinol. 11:438. doi: 10.3389/fendo.2020.00438
Leptin affects food intake regulation and energy homeostasis in mammals, as opposed to mammals who have a single leptin gene, fish have duplicated leptin gene paralogues. Until now, most functional studies on fish focused on the first reported paralogue without much explanation on specific gene paralogue. This study successfully expressed two homologous recombinant mandarin fish leptin genes (LepA and LepB) for the first time. To explore the differential roles of these two gene paralogues involved in food intake and energy homeostasis, mandarin fish were treated with homologous recombinant LepA and LepB proteins by acute IP administration. The results showed that LepB inhibited the food intake of mandarin fish after acute IP administration through modifying the expressions of hypothalamic orexigenic genes, while LepA had no significant effect on its food intake. In addition, LepB administration decreased the hepatic glycogen level through regulating the gene expressions of glycogen synthase and glycogen phosphorylase in mandarin fish until $4 \mathrm{~d}$, while LepA did not change the hepatic glycogen level as it failed to change the expressions of these regulatory genes. Moreover, LepA and LepB downregulated the expressions of key gluconeogenic genes (phosphofructokinase, phosphoenolpyruvate carboxykinase, and glucose-6-phosphatase), indicating both mandarin fish leptins could regulate the rate of glucose production. However, these two gene paralogues presented secondary effects on lipid metabolism as they only enhanced the triglyceride level by modifying the gene expressions of adipose triglyceride lipase or acetyl CoA carboxylase just for $1 \mathrm{~d}$ after IP. Therefore, LepB played an important role in food intake and glucose homeostasis regulation, while LepA showed a limited role in gluconeogenesis and lipid metabolism.

Keywords: fish leptin, food intake, appetite, hepatic glycogen, gluconeogenesis, triglyceride

\section{INTRODUCTION}

Leptin plays an important role in weight control, lipid metabolism, energy homeostasis, and reproduction in mammals $(1,2)$. A large amount of studies on leptin have been carried out all over the world ( $>823,000$ published manuscripts; ISI search April 2020). Moreover, leptin has been regarded as a satiety signaling factor in food intake regulation in recent decades (3-5). 
As opposed to mammals who have a single leptin gene, fish leptins diverged into duplicated leptin gene paralogues (6-8) after a major genome replication event in the fish lineage about 300 million years ago. The divergent leptin gene paralogues have been cloned in several species of fish, including zebrafish (Danio rerio) (7), carp (Cyprinus carpio) (9), Atlantic salmon (Salmo Salar) (10, 11), medaka (Oryzias latipes) (12), and orange-spotted grouper (Epinephelus coioides) (13). However, the differential functions of the two leptin gene paralogues were only studied in goldfish (Carassius auratus), zebrafish and Whiteclouds Mountain minnow (Tanichthys albonubes), and limited to the effect of energy on the gene expression of divergent leptins (14-16).

The functional studies of leptin have been gradually proceeded since its discovery. Acute and chronic intraperitoneal injection (IP) leptin administrations reduced food intake and body weight in goldfish, which were consistent with the results in mammals (17). However, peripheral treatment with mammalian leptin in immature coho salmon (Oncorhynchus kisutch) (18) or green sunfish (Lepomis cyanellus) (19) did not change their feeding behavior or energy metabolism. The contradictory results are probably due to the large difference in the amino acid sequences of leptin between fish and mammals. Therefore, it is indispensable and important to use the homologous protein to study the physiological function of leptin on fish.

Mandarin fish (Siniperca chuatsi Basilewsky) which is a demersal piscivore, is found only in the freshwaters of China and the River Amur along the Russian borderlands (20). It is one of the chief economic freshwater fishes in China due to its fast growth and delicious flesh (21). In recent years, the aquaculture of mandarin fish has been developed rapidly. The production of this fish overall was 315,906 t in the year 2018 and this amount is only from China. In addition, it has a unique food preference, since it feeds solely on live fry of other fish species and once the fry start feeding in the wild (22). The mandarin fish leptin A (LepA) and leptin B (LepB) genes have been cloned in our previous study (23). In the present study, to explore the differential functions of leptin on food intake and energy metabolism, we treated mandarin fish with the homologous recombination LepA and LepB through intraperitoneal injection.

\section{METHODS AND MATERIALS}

\section{Animals and Samples}

The experimental mandarin fish (initial body weight: 14.58 $\pm 0.33 \mathrm{~g}$ ) was purchased from Wuhan Sihui Fishery (Wuhan, Hubei, China) and stored in a 300-L tank at Huazhong Agricultural University. Animal experiments were approved by the ethical committee of Huazhong Agricultural University. The

Abbreviations: $a c c$, Acetyl CoA carboxylase; $a c t b$, Actin beta; atgl, Adipose triglyceride lipase; agrp, Agouti-related protein; $b 2 \mathrm{~m}$, Beta-2-microglobulin; cart, Cocaine- and amphetamine-regulated transcript protein precursor; $g 6 p c$, Glucose6-phosphatase; gys, Glycogen synthase; pygl, Glycogen phosphorylase; hmbs, Hydroxymethylbilane synthase; $n p y$, Neuropeptide Y; $p f k l$, 6-phosphofructokinase 1; pepck, Phosphoenolpyruvate carboxykinase; pomc, Proopiomelanocortin; rpl13a, Large subunit ribosomal protein L13Ae; sdha, Succinate dehydrogenase complex flavoprotein subunit A; tub $\alpha 1 a$, Tubulin alpha-1A chain. fish were acclimated to the experimental conditions for 2 weeks. During acclimation, fish were fed to apparent satiation with Cirrhinus mrigala twice a day at 9:00 and 17:00, respectively. After the 2-weeks acclimation, six mandarin fishes used for the cloning and recombinant expression of leptin proteins were randomly selected and then anesthetized with MS-222 (200 mg/L). The liver samples were collected and frozen immediately in liquid nitrogen and stored at $-80^{\circ} \mathrm{C}$ until used.

\section{Construction of Recombinant Plasmids of Leptins}

Liver RNA extraction and cDNA transcription were performed with Trizol reagent (Takara, Japan) and PrimeScript ${ }^{\mathrm{TM}}$ RT reagent Kit with gDNA Eraser (Takara) according to the manufacturer's protocols. The quantity and quality of RNA obtained were checked by spectrophotometric analysis with the Eppendorf Biophotometer Plus; ratio of absorbance at 260 and $280 \mathrm{~nm}\left(A_{260} / A_{280}\right)$ was used to assess purity of RNA and $A_{260} / A_{280}$ ratios above 2.0 for RNA were controlled.

The full-length of mRNA sequences of the mandarin fish leptins were obtained from our previous study (23). Primers were designed on the complete coding sequences of mature proteins (Table 1) referred to the ClonExpress II One Step Cloning Kit (Vazyme Biotech, Jiangsu, China). Then, using cDNA from the liver of mandarin fish as the template, the products of complete coding sequence of LepA and LepB mature proteins were amplified first. The PCR products were purified from agarose gel and verified by DNA sequencing (Sangon Biotech, Shanghai, China). The purified PCR products of complete coding sequences of LepA and LepB mature proteins were then subcloned into the pET30a vector (Invitrogen, Carlsbad, CA) using ClonExpress ${ }^{\mathrm{TM}}$ II One Step Cloning Kit (Vazyme Biotech), respectively. The recombinant LepA-pET30a and LepB-pET30a plasmids were transformed into E. coli $\mathrm{DH} 5 \alpha$ using heat shock transformation. Positive transformants were selected, and inserts were sequenced to confirm the proper sequence.

\section{Protein Expression and Purification}

The recombinant LepA-pET30a and LepB-pET30a plasmids were transformed into the competent BL21 (DE3) E. coli strain for protein expression. Transformed cells were grown in $4 \mathrm{~L}$ of LuriaBroth (LB) medium containing $30 \mu \mathrm{g} / \mathrm{mL}$ ampicillin at $37^{\circ} \mathrm{C}$. When absorbance at $600 \mathrm{~nm}$ reached 0.6, IPTG (isopropyl bD-1-thiogalactopyranoside) was added to a final concentration of $0.5 \mathrm{mM}$. Cells were cultivated for another $4 \mathrm{~h}$ and then they were harvested by centrifugation at $6,000 \mathrm{~g}$ for $15 \mathrm{~min}$ at $4^{\circ} \mathrm{C}$. The cells were resuspended in $100 \mathrm{ml}$ of cell lysis buffer $(8 \mathrm{M}$ Urea, $50 \mathrm{mM}$ Tris, $300 \mathrm{mM} \mathrm{NaCl}, 1 \mathrm{mM}$ DTT, $0.2 \%$ TritonX$100, \mathrm{pH}=8.0$ ), and disrupted by sonication. Inclusion bodies were separated from the cell lysate by centrifugation at $14,000 \mathrm{~g}$ for $20 \mathrm{~min}$ at $4^{\circ} \mathrm{C}$.

A Ni-NTA agarose column was equilibrated with $5 \mathrm{~mL}$ binding buffer ( $8 \mathrm{M}$ Urea, $50 \mathrm{mM}$ Tris, $300 \mathrm{mM} \mathrm{NaCl}, 1 \mathrm{mM}$ DTT, $0.2 \%$ TritonX-100, $\mathrm{pH}=8.0$ ). Then the column was loaded with reaction solution at a rate of $2 \mathrm{~mL} / \mathrm{min}$, and then washed with washing buffer ( $8 \mathrm{M}$ Urea, $50 \mathrm{mM}$ Tris, $300 \mathrm{mM} \mathrm{NaCl}, 1 \mathrm{mM}$ DTT, $0.2 \%$ TritonX-100, $10 \mathrm{mM} / 20 \mathrm{mM} / 50 \mathrm{mM}$ Imidazole, 
TABLE 1 | Primers of recombinant plasmids construction.

\begin{tabular}{|c|c|c|c|}
\hline Primer & Sequence $5^{\prime}-3^{\prime}$ & AL (bp) & Genbank \\
\hline LepA-IFor & GTACCGACGACGACGACAAGGCTCCTCTGCCAGTGGAAGTA & 449 & KC778775 \\
\hline LepA-sFor & GCTCCTCTGCCAGTGGAAGTAGTGAAG & 449 & \\
\hline LepA-IRev & GACGGAGCTCGAATTCGGATTTATCAGCAAGTCTTA & & \\
\hline LepB-IFor & GTACCGACGACGACGACAAGCTTCCCACGAAGGGAGACTCCATC & 437 & KP993203 \\
\hline LepB-sFor & CTTCCCACGAAGGGAGACTCCATCAG & 437 & \\
\hline LepB-IRev & GACGGAGCTCGAATTCGGATTTAGCAGACCTTGAGTTGTCTTTG & & \\
\hline pET30a-IFor & ATCCGAATTCGAGCTCCGTCGACAAG & 5,963 & \\
\hline pET30a-sRev & CCAGATCTGGGCTGTCCATGTGCT & & \\
\hline pET30a-sFor & GACAAGCTTGCGGCCGCACT & 5,863 & \\
\hline
\end{tabular}

$\mathrm{pH}=8.0)$. The protein was eluted with elution buffer ( $8 \mathrm{M}$ Urea, $50 \mathrm{mM}$ Tris, $300 \mathrm{mM} \mathrm{NaCl}, 1 \mathrm{mM}$ DTT, $500 \mathrm{mM}$ Imidazole, $\mathrm{pH}$ $=8.0$ ). The eluates were then dialyzed against PBS $(\mathrm{pH}=7.5)$ for $12 \mathrm{~h}$ and finally sterile filtered through a $0.45 \mu \mathrm{m}$ cellulose acetate syringe filter. Eluates were collected and analyzed for SDS-PAGE and Western blotting.

\section{SDS-PAGE and Western Blotting}

The samples of the eluates were subjected to SDS-PAGE on a $12 \%$ acrylamide gel to confirm the expected size of the proteins. Protein concentrations of LepA and LepB were determined with a Non-Interference Protein Assay Kit (Sangon Biotech) using the BSA as a standard.

The inclusion body fraction containing the recombinant LepA and LepB was subjected to SDS-PAGE, and the resolved protein bands were electrophoretically transferred to polyvinylidene fluoride (PVDF) membranes (Sangon Biotech). The membranes were blocked with $5 \%$ non-fat dry milk in Tris-buffered saline containing $0.5 \%$ Triton $\mathrm{X}-100$ at $4^{\circ} \mathrm{C}$ overnight. The blocked membranes were incubated with 1:1000 dilution of mouse anti-His antibody at $37^{\circ} \mathrm{C}$ for $0.5 \mathrm{~h}$, and $1: 1500$ dilution of goat anti-mouse IgG horse radish peroxidase conjugate was added and incubated at $37^{\circ} \mathrm{C}$ for $0.5 \mathrm{~h}$. Then, the derived proteins were eluted, desalted and freeze-dried. The freezedried proteins were dissolved in $0.1 \%$ TFA, and then analyzed by 4800 plus MALDI-TOF-TOF Analyzer (AppliedBiosystems, USA). The data obtained from the first and second mass spectrometric analysis were analyzed by GPS Explore v3.6 software (AppliedBiosystems, USA). The protein was then identified by searching in the local database using MASCOT v2.1 (Matrix Science, UK) software.

\section{Effects of Acute IP LepA and LepB Administration on Food Intake}

The effect of homologous recombinant LepA and LepB proteins we purified as mentioned above on the food intake of mandarin fish was studied by acute IP administration. Experimental mandarin fish were obtained from the tanks at the Huazhong
Agricultural University we reared before. After a 2-weeks acclimation, 54 mandarin fishes were deprived of food for $24 \mathrm{~h}$ before IP and then anesthetized with MS-222 (100 mg/L). Then, each experimental fish was weighed to calculate the injection dose of IP. After IP, fish were randomly distributed into nine groups. Each experimental group was provided with six duplicate tanks $(60 \mathrm{~L})$, and only one mandarin fish was reared in each of these six biology repetitions. The nine experimental groups were set as: Four groups injected with 100, 500, 1,000, and 1,500 ng/g BW LepA protein (dissolved in DPBS, named A100, A500, A1000, and A1500 groups, respectively); Four groups injected with 100, $500,1,000$, and 1,500 ng/g BW LepB protein (dissolved in DPBS, named B100, B500, B1000, and B1500 groups, respectively); The other one group injected with vehicle with equal volume named the control group. The injection doses of LepA and LepB proteins in mandarin fish were referred to the dose reported in previous studies $(17,24-27)$. Before injection, equal and excessive $C$. mrigala (prey fish, $0.16 \pm 0.003 \mathrm{~g}$ ) was put into each white plastic tank. Then, the numbers of prey fish remaining in the tanks were recorded as photographs before and 2 and $4 \mathrm{~h}$ after the injection. The sampling time ( 2 and $4 \mathrm{~h}$ after the injection) of LepA and LepB administrations affected the food take of mandarin fish were referred to the sampling time reported in previous studies (24-26). Three legible pictures clearly showed the number of prey fish that were selected in each white plastic tank at each time, and the average number of the prey fish was taken into account. The food intake of the experimental group $=$ (the initial amount of prey fish - the rest amount of prey fish at 2 or $4 \mathrm{~h}) \times$ the average weight of prey fish / the body weight of the mandarin fish.

\section{Effects of Acute IP LepA and LepB Administration on Biochemical Indexes}

The effects of homologous recombinant protein LepA and LepB we purified as mentioned above on hepatic glycogen, triglyceride (TG), and cholesterol (CHO) of mandarin fish were studied by acute IP administration. After the 2-weeks acclimation, mandarin fish were deprived of food for $24 \mathrm{~h}$ before IP and then anesthetized with MS-222 (100 mg/L). Then, each experimental 
fish was weighed to calculate the injection dose of IP. After IP, fish were randomly distributed into nine groups, each set with triplicate groups in plastic tanks $(300 \mathrm{~L})$. The density of each tank is 40 fishes. The nine experimental groups were set as: Four groups injected with 100, 500, 1,000, and 1,500 ng/g BW LepA protein (dissolved in DPBS, named A100, A500, A1000, and A1500 groups, respectively); Four groups injected with 100, $500,1,000$, and 1,500 ng/g BW LepB protein (dissolved in DPBS, named B100, B500, B1000, and B1500 groups, respectively); The other one group injected with vehicle with equal volume was named the control group. Fish were fed with equal and excessive C. mrigala (prey fish, $0.16 \pm 0.003 \mathrm{~g}$ ) during the 7 days maintaining period. At 9:00 am of 1, 2, 4, and $7 \mathrm{~d}$ after injection, six fishes were randomly taken out from each tank, then anesthetized with MS-222 (200 mg/L). The sampling time $(1,2,4$, and $7 \mathrm{~d}$ after injection) of LepA and LepB administrations affected the biochemical indexes of mandarin fish and were referred to the sampling time reported in previous studies (17, $27,28)$. The liver of each fish was collected quickly and stored at $-20^{\circ} \mathrm{C}$ until used for the detection of glycogen, triglyceride, and cholesterol.

\section{Effects of IP LepA and LepB Administration on Gene Expressions Related to Appetite and Energy Homeostasis}

The effects of the homologous recombinant protein LepA and LepB, which we purified as mentioned above on orexigenic (Neuropeptide Y, $n p y$; Agouti-related protein, agrp) and anorexigenic (Cocaine- and amphetamine-regulated transcript protein precursor, cart; Proopiomelanocortin, pomc) genes of mandarin fish were studied by acute IP administration. After the 2-weeks acclimation, mandarin fish were deprived of food for $24 \mathrm{~h}$ before IP and then anesthetized with MS-222 (100 $\mathrm{mg} / \mathrm{L})$. Then, each experimental fish was weighed to calculate the injection dose of IP. After IP, fish were randomly distributed into nine groups, each set with triplicate groups in plastic tanks $(300 \mathrm{~L})$. The density of each tank is 50 fishes. The nine experimental groups were set as: Four groups injected with 100, $500,1,000$, and $1,500 \mathrm{ng} / \mathrm{g}$ BW LepA protein (dissolved in DPBS, named A100, A500, A1000, and A1500 groups, respectively); Four groups injected with 100, 500, 1,000, and 1,500 ng/g BW LepB protein (dissolved in DPBS, named B100, B500, B1000, and B1500 groups, respectively); The other one group injected with vehicle with equal volume was named the control group. At 2 and $4 \mathrm{~h}$ after injection, four fishes were randomly taken out from each tank, then anesthetized with MS-222 (200 mg/L). The brain of each fish was collected quickly, frozen immediately in liquid nitrogen, and stored at $-80^{\circ} \mathrm{C}$ until used for appetite gene expression.

Then, the effects of the homologous recombinant protein LepA and LepB we purified as mentioned above on energy homeostasis genes (Glucose metabolism related genes: Glycogen synthase, gys; Glycogen phosphorylase, pygl; 6-phosphofructokinase 1, pfkl; Phosphoenolpyruvate carboxykinase, pepck; Glucose-6-phosphatase, g6pc; Lipid metabolism related genes: Acetyl CoA carboxylase, acc; Adipose triglyceride lipase, atgl) of mandarin fish were studied by acute IP administration. After the sample collection for appetite gene expression, the remaining fish in each tank were fed with equal C. mrigala (prey fish, $0.16 \pm 0.003 \mathrm{~g}$ ) during the 7 -days maintaining period. At 9:00 am of 1, 2, 4, and $7 \mathrm{~d}$ after injection, four fishes were randomly taken out from each tank of DPBS, $1,000 \mathrm{ng} / \mathrm{g}$ LepA and 1,000 ng/g LepB groups, then anesthetized with MS-222 $(200 \mathrm{mg} / \mathrm{L})$. The liver of each fish was collected quickly, frozen immediately in liquid nitrogen, and stored at $-80^{\circ} \mathrm{C}$ until used for energy homeostasis gene expression.

RNA extraction and cDNA transcription were performed with Trizol reagent (Takara, Japan) and a PrimeScript ${ }^{\mathrm{TM}}$ RT reagent Kit with gDNA Eraser (Takara) according to the manufacturer's protocols. Real-time PCR assays were carried out on a quantitative thermal cycler (CFX Connect RealTime System, BIO-RAD, Hercules, CA, USA) using AceQ ${ }^{\circledR}$ qPCR SYBR ${ }^{\circledR}$ Green Master Mix (Vazyme Biotech) with the designed primers (Table 2). A set of six housekeeping genes (actb, rpl13a, tuba 1a, b2m, hmbs, and sdha) were selected from the transcriptome assemblies (29) to test their transcription stability for tissue panel. GeNorm software was used to compute the expression stability values (M) for each gene where a lower $M$ value corresponds to more stable gene expression. The PCR parameters were $95^{\circ} \mathrm{C}$ for $3 \mathrm{~min}$ followed by 40 cycles at $95^{\circ} \mathrm{C}$ for $10 \mathrm{~s}$, annealing temperature for $30 \mathrm{~s}$, and a melt curve step. Primer PCR efficiencies of the genes ranged from 96.7 to $105.0 \%$. Gene expression levels were quantified relative to the expression of housekeeping genes using the optimized comparative $\mathrm{Ct}$ $\left(2^{-\Delta \Delta \mathrm{Ct}}\right)$ value method (30).

\section{Statistical Analysis}

All data were presented as mean \pm S.E.M (standard error of the mean). The normality of data was assessed by using SPSS software with the Shapiro-Wilk test. All data were subjected to one-way analysis of variance (one-way ANOVA) using the SPSS 17.0 software. Differences between the means were tested by Duncan's multiple range test after homogeneity of variances was checked. Statistical significance was determined at the $5 \%$ level.

\section{RESULTS}

\section{Effects of Acute IP LepA and LepB Administration on Food Intake and Appetite}

The change of food intake in mandarin fish at 2 and $4 \mathrm{~h}$ after acute LepA and LepB administration was presented in Figure 1. At 2 and $4 \mathrm{~h}$ after IP administration, LepA groups had no significant difference with the vehicle group, while all LepB treated groups had significantly decreased food intake compared with the vehicle group $(P<0.05)$. At $2 \mathrm{~h}$ after IP administration under 500, 1,000, and 1,500 ng/g BW doses, the food intake of the mandarin fish was significantly higher under LepA administration than LepB $(P<0.05)$. At $4 \mathrm{~h}$ after IP administration under 1,000 and $1,500 \mathrm{ng} / \mathrm{g} \mathrm{BW}$ doses, the 
TABLE 2 | Primer sequences for gene expression.

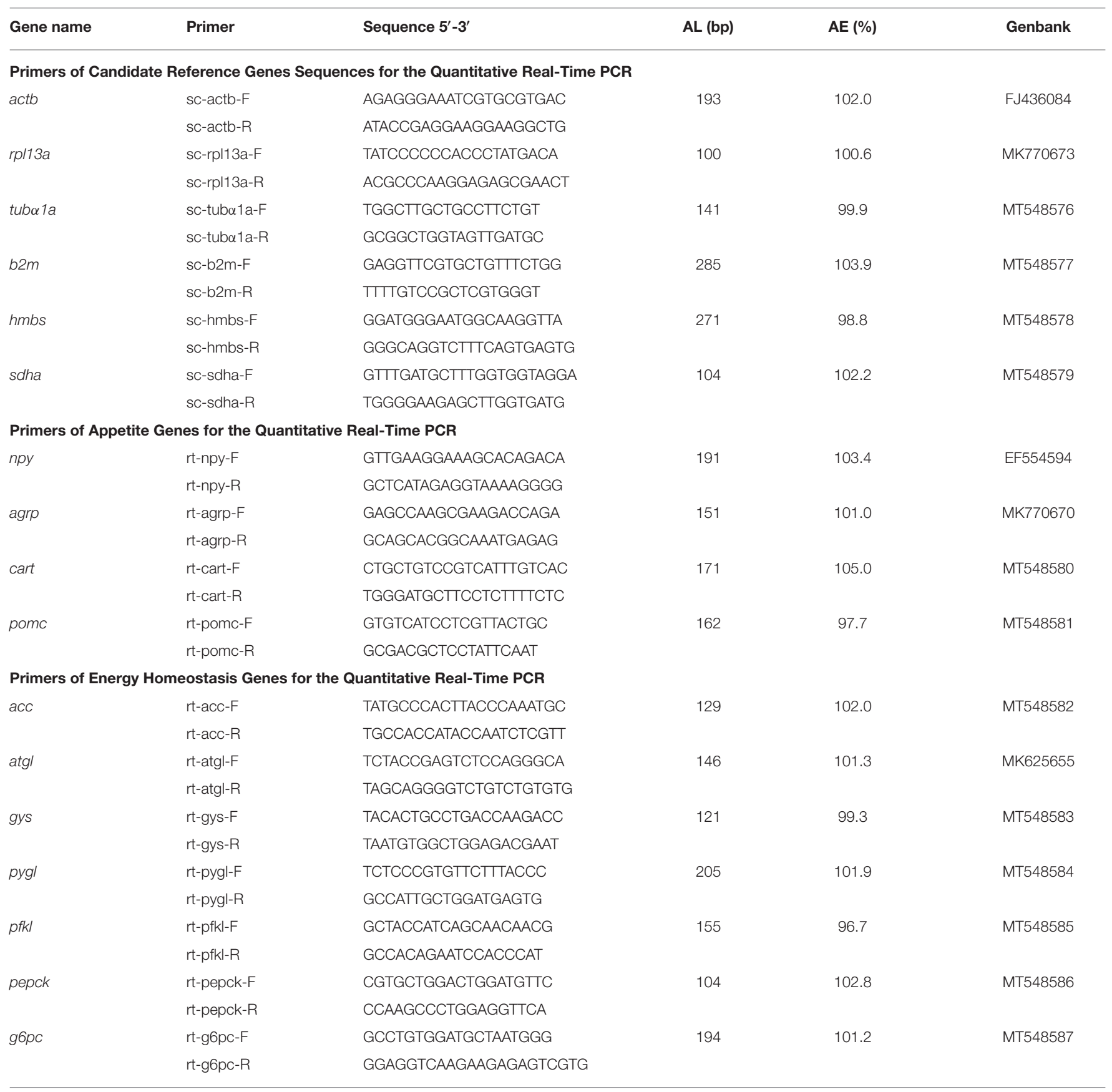

food intake of mandarin fish was significantly higher after LepA administration than LepB $(P<0.05)$.

At 2 and $4 \mathrm{~h}$ after IP LepA and LepB administration, the mRNA abundances of appetite genes in mandarin fish were presented in Figure 2. At $2 \mathrm{~h}$ after IP administration, the expressions of orexigenic genes, $n p y$ and agrp, in the brain of mandarin fish treated with LepA and LepB proteins were significantly lower than the fish treated with vehicle $(P$ $<0.05)$. At $2 \mathrm{~h}$ after IP administration, the expressions of anorexigenic genes, cart and pomc, in the brain of mandarin fish treated with LepA protein were significantly lower than the fish treated with the vehicle $(P<0.05)$, while no significantly difference was seen in these two gene expressions between LepB and vehicle administrations. In addition to the gene expression of agrp was significantly decreased at $4 \mathrm{~h}$ after LepB administration under 100 and $500 \mathrm{ng} / \mathrm{g}$ BW doses compared with the control group, no significant differences were observed in the appetite gene expressions among the other LepA and LepB administrations and vehicle administration at $4 \mathrm{~h}$ after IP administration. 

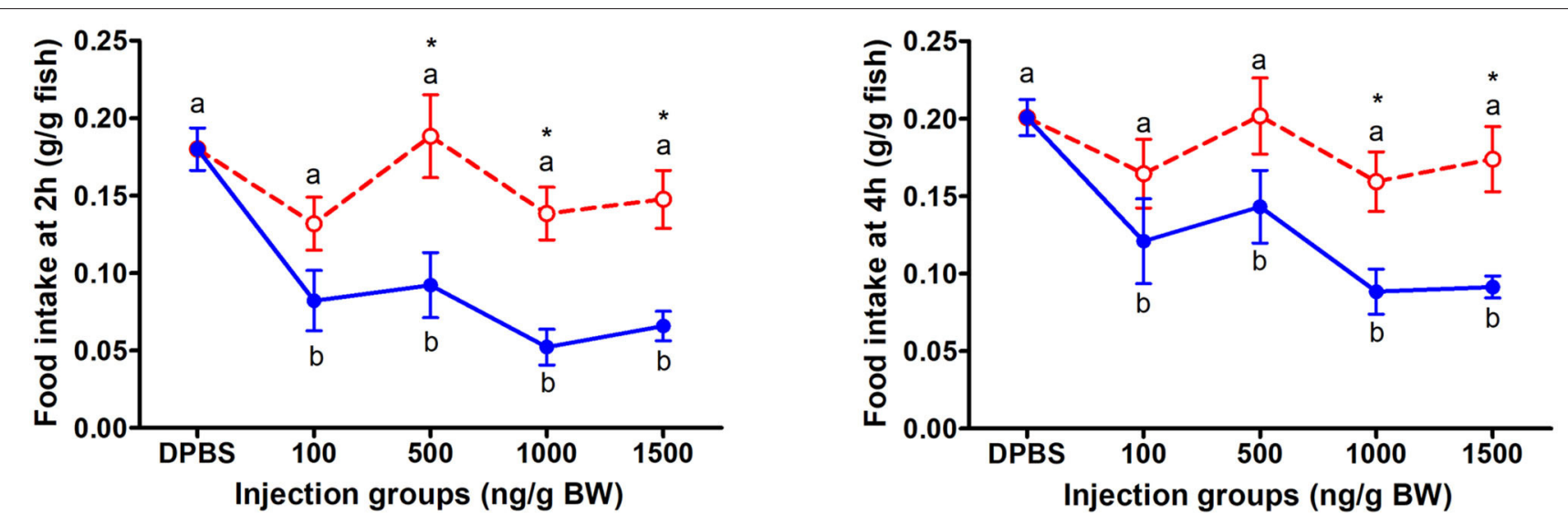

FIGURE 1 | The effects of intraperitoneal administration of LepA (red dotted line) and LepB (blue solid line) on food intake at 2 and 4 h. Data represent means \pm S.E.M $(n=6)$. Significance level are marked with different letters $(P<0.05)$, compared with the values from DPBS injected mandarin fish. Mean values with an asterisk $\left({ }^{*}\right)$ above show significant differences between fish groups injected with leptin A and leptin B at the same dose $(P<0.05)$.

\section{Effects of Acute IP LepA and LepB Administration on Glucose Metabolism}

The effect of acute IP LepA and LepB administration on hepatic glycogen was presented in Figure 3. LepB significantly decreased the hepatic glycogen at $2 \mathrm{~d}$ after administration under 100, 500 , and $1,000 \mathrm{ng} / \mathrm{g} \mathrm{BW}$ doses $(P<0.05)$. At $4 \mathrm{~d}$ after IP administration, the hepatic glycogen was significantly reduced by the LepB treatment at $1,000 \mathrm{ng} / \mathrm{g} \mathrm{BW}(P<0.05)$. At 1 and $7 \mathrm{~d}$ after IP administration, LepB had not modified the hepatic glycogen. There were no significant differences observed in the hepatic glycogen under acute IP LepA administration.

In order to explore the molecular mechanism of hepatic glycogen changes, we further detected the expressions of key genes related to glucose metabolism by acute IP LepA and LepB administrations at $1,000 \mathrm{ng} / \mathrm{g}$ BW treated dose (as shown in Table 3). As expected, the expression of the key enzyme for glycogen synthesis, gys, was significantly lower in acute IP LepB administration compared with the vehicle at 1,2 , and $4 \mathrm{~d}$ $(P<0.05)$. Correspondingly, the gene expression of glycogen phosphorylase ( $p y g l$ ) was significantly enhanced by the IP LepB administration compared with the vehicle at $4 \mathrm{~d}(P<0.05)$. No significant difference was seen in gys or pygl expression under IP LepA administration at different time points compared with the vehicle treatment. Meanwhile, LepA and LepB also shifted the expression of three key genes for gluconeogenesis ( $p f k l$, pepck, and $g 6 p c)$. At $1 \mathrm{~d}$ after treatments, both LepA and LepB significantly decreased the mRNA abundances of pepck and $g 6 p c$ compared with the vehicle $(P<0.05)$. At $2 \mathrm{~d}$ after IP administrations, LepA significantly decreased the mRNA abundance of $g 6 p c$, and LepB significantly reduced the mRNA abundances of $p f k l$, pepck, and $g 6 p c$ compared with the vehicle $(P$ $<0.05)$. The gene expressions of $p f k l$ and pepck were significantly decreased in both LepA and LepB administration compared with the vehicle at $4 \mathrm{~d}$ after treatments $(P<0.05)$. At $7 \mathrm{~d}$ after treatments, neither LepA nor LepB could modify the gene expressions of these three gluconeogenic genes.

\section{Effects of Acute IP LepA and LepB Administration on Lipid Metabolism}

The effects of acute IP LepA and LepB administration on cholesterol (CHO) and triglyceride (TG) in the liver were presented in Figures 4, 5, respectively. No significant difference was seen in hepatic cholesterol under IP LepA or LepB administration at different time points compared with the vehicle treatment. At $1 \mathrm{~d}$ after treatments, LepA significantly enhanced the hepatic triglyceride at 1,000 and 1,500 ng/g BW doses, and LepB significantly increased the hepatic triglyceride at 100, 1,000, and $1,500 \mathrm{ng} / \mathrm{g} \mathrm{BW}$ doses compared with the vehicle $(P<0.05)$. No significant difference was seen in hepatic triglyceride under acute IP LepA or LepB administration after $1 \mathrm{~d}$ compared with the vehicle treatment.

In order to explore the modulator mechanism of hepatic triglyceride changes, we further detected the expressions of key genes related to lipid metabolism by IP LepA and LepB administrations at 1,000 ng/g BW treated doses (Table 3). At 1 $\mathrm{d}$ after IP administrations, LepA significantly reduced the mRNA abundance of the key enzyme for triglyceride lipase (atgl), and LepB significantly increased the mRNA abundance of the key enzyme for triglyceride synthesis ( $a c c$ ) compared with the vehicle group at the same time $(P<0.05)$. But in addition to that, no significant differences were seen in gene expressions of acc and atgl under acute IP LepA or LepB administration after $1 \mathrm{~d}$ compared with the vehicle treatment.

\section{DISCUSSION}

Leptin is involved in energy homeostasis and growth regulation as a satiety signal in mammals $(31,32)$. However, the relationship between energy state and leptin has not been fully elucidated in fish (14). As opposed to mammals who have a single leptin gene, fish have duplicated leptin gene paralogues. Until now, almost functional studies on fish focused on the first 

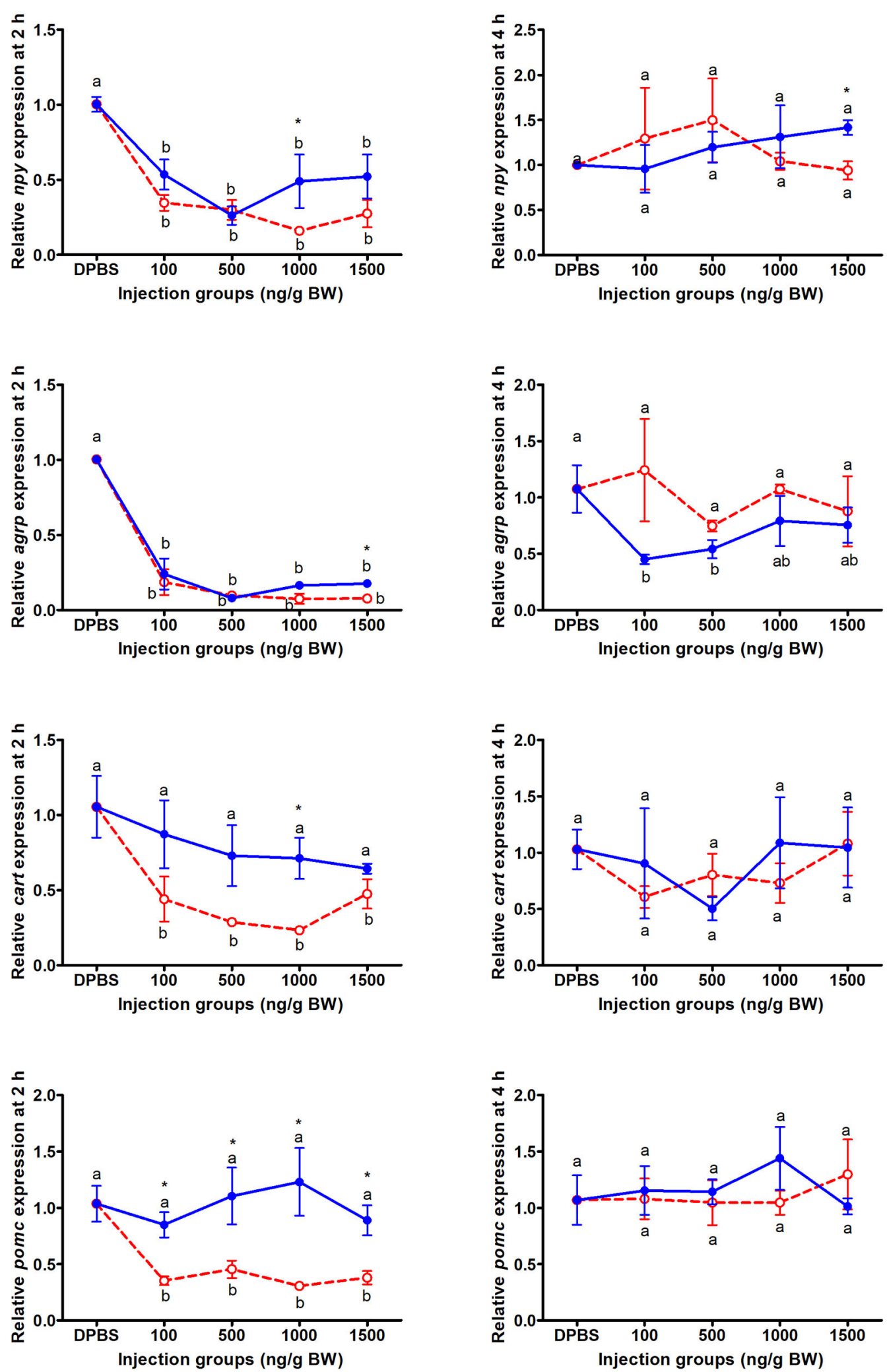

FIGURE 2 | The expressions of appetite genes after acute LepA (red dotted line) and LepB (blue solid line) administration. Data represent means \pm S.E.M ( $n=4)$. Significance level are marked with different letters $(P<0.05)$, compared with the values from DPBS injected mandarin fish. Mean values with an asterisk $\left(^{\star}\right)$ above show significant differences between fish groups injected with leptin A and leptin B at the same dose $(P<0.05)$. 

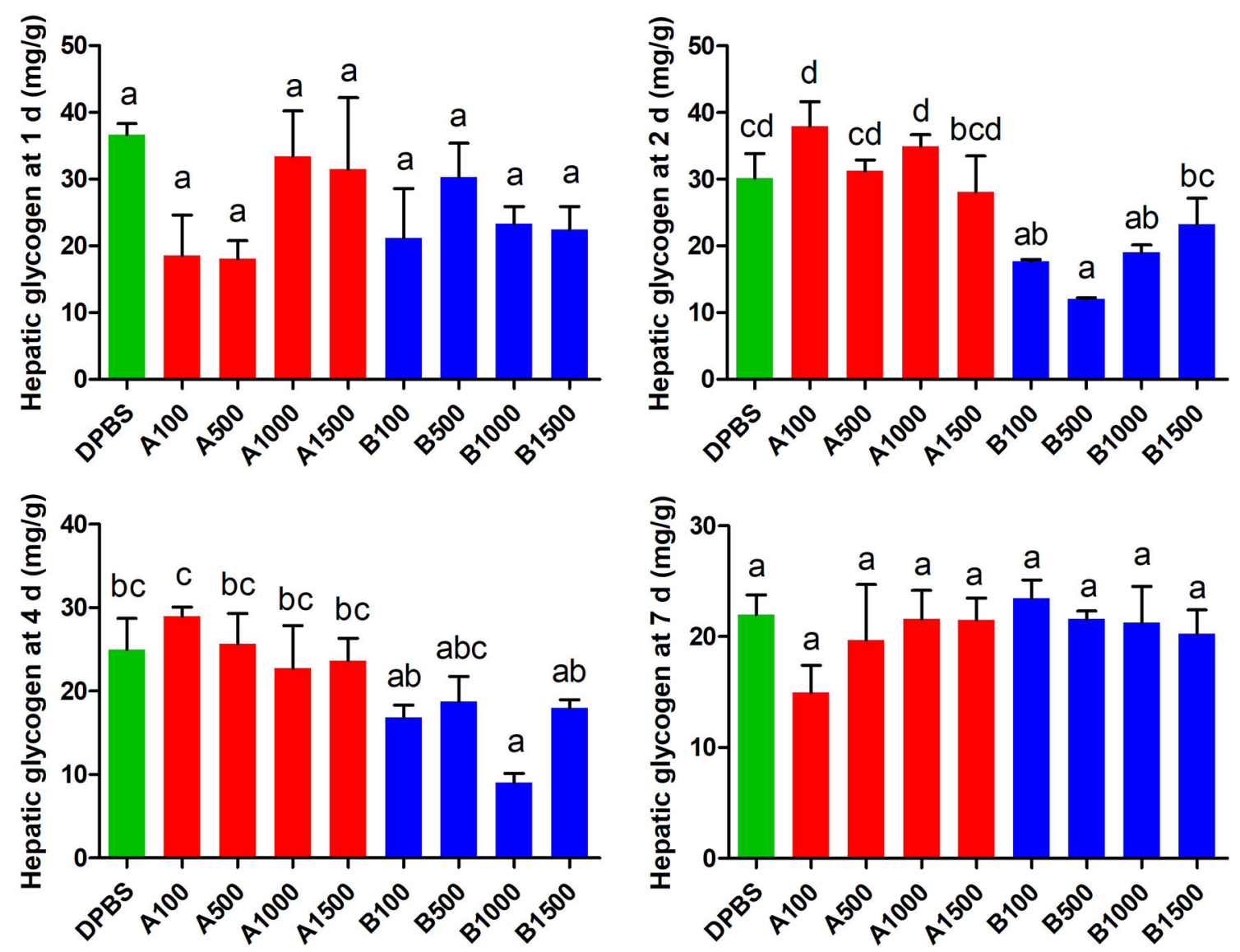

FIGURE 3 | The effects of intraperitoneal injection of LepA and LepB on hepatic glycogen levels at 1, 2, 4, and 7 d. Data represent means \pm S.E.M ( $n=6$ ). The colors of bars were shaded according to intraperitoneal injection of different solvent (green: DPBS, red: LepA, blue: Lep B). Significance level are marked with different letters $(P<0.05)$, compared with the values from DPBS injected mandarin fish.

TABLE 3 | The expressions of genes related to energy homeostasis after LepA and LepB administration.

\begin{tabular}{|c|c|c|c|c|c|c|c|c|}
\hline Time & Treatment & gys & pygl & pfkl & pepck & $g 6 p c$ & acc & atgl \\
\hline \multirow[t]{3}{*}{$1 d$} & DPBS & $1.02 \pm 0.10^{b}$ & $0.92 \pm 0.20^{a}$ & $0.85 \pm 0.05^{a}$ & $1.02 \pm 0.11^{b}$ & $1.01 \pm 0.09^{c}$ & $1.12 \pm 0.10^{\mathrm{a}}$ & $1.07 \pm 0.23^{b}$ \\
\hline & LepA (1,000 ng/g BW) & $0.77 \pm 0.13^{\mathrm{ab}}$ & $0.71 \pm 0.06^{a}$ & $1.31 \pm 0.15^{a}$ & $0.42 \pm 0.15^{a}$ & $0.05 \pm 0.01^{a}$ & $1.58 \pm 0.27^{\mathrm{ab}}$ & $0.28 \pm 0.08^{a}$ \\
\hline & LepB (1,000 ng/g BW) & $0.62 \pm 0.07^{a}$ & $0.94 \pm 0.14^{\mathrm{a}}$ & $1.08 \pm 0.22^{a}$ & $0.07 \pm 0.04^{a}$ & $0.43 \pm 0.18^{b}$ & $2.34 \pm 0.33^{b}$ & $1.53 \pm 0.14^{b}$ \\
\hline \multirow[t]{3}{*}{$2 d$} & DPBS & $1.23 \pm 0.37^{b}$ & $1.23 \pm 0.49^{a}$ & $1.17 \pm 0.14^{\mathrm{b}}$ & $1.17 \pm 0.14^{b}$ & $1.17 \pm 0.08^{b}$ & $1.04 \pm 0.15$ & $0.90 \pm 0.14$ \\
\hline & LepA $(1,000$ ng/g BW) & $0.73 \pm 0.16^{a b}$ & $0.87 \pm 0.15^{a}$ & $0.99 \pm 0.12^{a b}$ & $1.12 \pm 0.10^{b}$ & $0.72 \pm 0.20^{a}$ & $0.86 \pm 0.17$ & $0.89 \pm 0.20$ \\
\hline & LepB (1,000 ng/g BW) & $0.26 \pm 0.07^{a}$ & $0.93 \pm 0.25^{a}$ & $0.66 \pm 0.07^{a}$ & $0.50 \pm 0.12^{a}$ & $0.71 \pm 0.11^{a}$ & $1.10 \pm 0.45$ & $1.16 \pm 0.35$ \\
\hline \multirow[t]{3}{*}{$4 d$} & DPBS & $1.02 \pm 0.13^{b}$ & $0.82 \pm 0.22^{\mathrm{a}}$ & $1.51 \pm 0.15^{\mathrm{b}}$ & $1.55 \pm 0.30^{b}$ & $0.96 \pm 0.33^{a}$ & $1.23 \pm 0.23$ & $1.32 \pm 0.26$ \\
\hline & LepA (1,000 ng/g BW) & $0.78 \pm 0.09^{a b}$ & $1.00 \pm 0.08^{a b}$ & $1.04 \pm 0.16^{a}$ & $0.84 \pm 0.38^{a}$ & $0.67 \pm 0.09^{a}$ & $1.26 \pm 0.37$ & $1.28 \pm 0.35$ \\
\hline & LepB (1,000 ng/g BW) & $0.44 \pm 0.19^{a}$ & $1.47 \pm 0.07^{\mathrm{b}}$ & $0.94 \pm 0.04^{a}$ & $0.83 \pm 0.33^{a}$ & $0.52 \pm 0.03^{a}$ & $1.32 \pm 0.18$ & $1.03 \pm 0.24$ \\
\hline \multirow[t]{3}{*}{$7 d$} & DPBS & $1.07 \pm 0.21$ & $1.09 \pm 0.26$ & $1.31 \pm 0.32$ & $1.08 \pm 0.26$ & $0.72 \pm 0.10$ & $1.02 \pm 0.17$ & $1.48 \pm 0.28$ \\
\hline & LepA (1,000 ng/g BW) & $1.36 \pm 0.15$ & $0.96 \pm 0.22$ & $1.54 \pm 0.36$ & $1.18 \pm 0.35$ & $1.30 \pm 0.41$ & $1.10 \pm 0.29$ & $1.48 \pm 0.05$ \\
\hline & LepB (1,000 ng/g BW) & $0.94 \pm 0.16$ & $0.76 \pm 0.09$ & $0.94 \pm 0.08$ & $1.29 \pm 0.36$ & $0.91 \pm 0.35$ & $1.11 \pm 0.15$ & $1.31 \pm 0.30$ \\
\hline
\end{tabular}

Data represent means \pm S.E.M $(n=4)$. Significance level are marked with different letters $(P<0.05)$, compared with the values from DPBS injected mandarin fish $(P<0.05)$.

reported paralogue without much explanation on specific gene paralogue $(15,33)$. Therefore, in order to explore the origin and physiological functions of tetrapod leptins, we successfully expressed leptin A and leptin B in fish for the first time based on our previous identification of the coding sequence of two mandarin fish leptin gene paralogues (23). Then, we further 

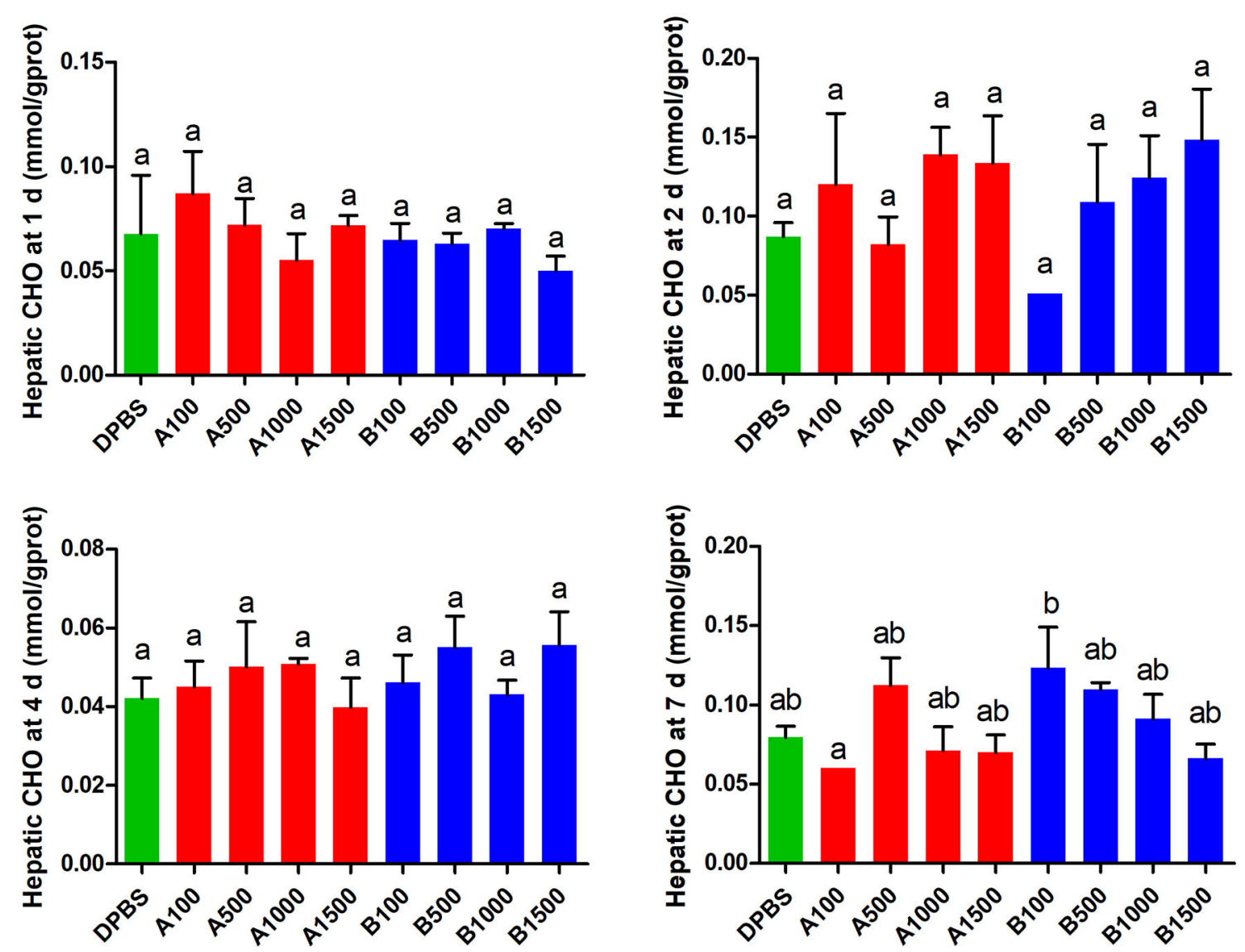

FIGURE 4 | The effects of intraperitoneal injection of LepA and LepB on hepatic CHO levels at 1, 2, 4, and 7 d. Data represent means \pm S.E.M ( $n=6$ ). The colors of bars were shaded according to intraperitoneal injection of different solvent (green: DPBS, red: LepA, blue: Lep B). Significance level are marked with different letters $(P<0.05)$, compared with the values from DPBS injected mandarin fish.

studied the functional differentiation of these two proteins in mandarin fish.

In the present study, LepB of mandarin fish presented an obvious effect of inhibiting food intake after acute IP administration through regulating the expressions of hypothalamic appetite genes. However, LepA had no significant effect on the food intake of mandarin fish. The effect of LepB on food intake in mandarin fish was consistent with that in mammals $(34,35)$. Leptin presented an inhibitory effect on food intake in most fish. Goldfish injected with recombinant mouse leptin (100 ng/g BW) showed a significant inhibitory effect on food intake within $1 \mathrm{~h}$ (24). Study on leptin in grass carp showed that the homologous recombinant protein significantly inhibited food intake and downregulated the expression of orexigenic gene, $n p y$, after a short-term IP treatment (2 h) (26). Murashita et al. (25) found that rainbow trout (Oncorhynchus mykiss) injected with homologous recombinant leptin intraperitoneally presented inhibited food intake, meanwhile the reduced $n p y$ and increased pomc expression within $2 \mathrm{~h}$, which was in parallel with the function of leptin in mammals on appetite regulation.

NPY and AgRP have been recognized as two of the most effective orexigenic proteins in mammals and fish (36-38).
POMC/CART neuron in the hypothalamus of mammals and fish are involved in the appetite suppression mediated by leptin (39-41). In this study, LepB suppressed the appetite of mandarin fish by inhibiting the expression levels of npy and agrp within $2 \mathrm{~h}$ after IP, and it further took effect until $4 \mathrm{~h}$ by decreasing the expression levels of agrp, which was in line with the decreased food intake induced by acute IP of LepB. In mammals, leptin regulated the food intake through NPY/AgRP and POMC/CART neurons in the arcuate nucleus of hypothalamus (39). However, it seems that LepB suppressed food intake only through the NPY/AgRP neuron in mandarin fish. Interestingly, mandarin fish LepA not only increased expression levels of $n p y$ and agrp, but also enhanced cart and pomc expressions at $2 \mathrm{~h}$ after IP without modifying the food intake of this fish. This result suggested that LepA might stimulate both NPY/AgRP and CART/POMC neurons within $2 \mathrm{~h}$ after IP, so that it failed to inhibit the food intake of mandarin fish. The exact physiological significance of this seemingly "ineffective" cycle needs to be further explored. In fact, the differential function of leptin has been preliminarily discussed in zebrafish. Gorissen et al. (7) reported that the mRNA abundance of leptin-b significantly decreased, while the leptin-a expression significantly increased in the liver of zebrafish after a 

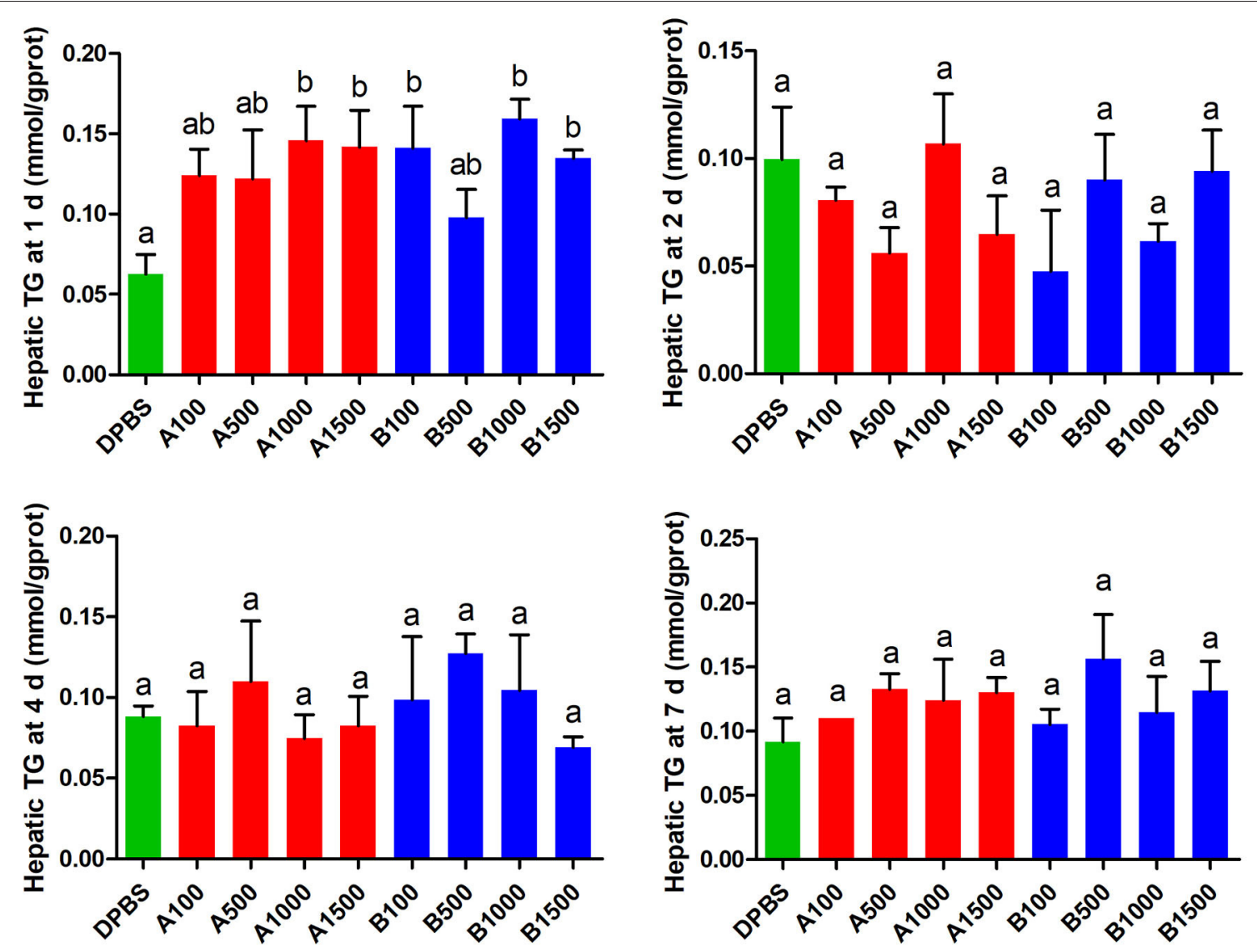

FIGURE 5 | The effects of intraperitoneal injection of leptin A and leptin B on hepatic TG levels at 1, 2, 4, and 7 d. Data represent means \pm S.E.M ( $n=6$ ). The colors of bars were shaded according to intraperitoneal injection of different solvent (green: DPBS, red: LepA, blue: Lep B). Significance level are marked with different letters $(P<0.05)$, compared with the values from DPBS injected mandarin fish.

week of fasting. Moreover, the more effective regulation of leptin $\mathrm{B}$ on food intake and appetite than leptin $\mathrm{A}$ in mandarin fish were similar to the results of our previous study, which claimed that leptin B might be more sensitive to the central nervous system (CNS) control of energy homeostasis than leptin A through a postprandial and short-term fasting treatment (23).

In addition to CNS, leptin also directly acts on the peripheral tissues of mammals, such as promoting glucose production in liver, regulating the efficiency of gluconeogenesis, or stimulating the generation of hepatic glycogen $(2,42)$. However, different responses in hepatic glycogen to leptin treatment were presented between fish and mammals. The hepatic glycogen of rainbow trout was decreased with the increasing intraventricular injection dose of leptin (43). IP of human or homologous leptin reduced the hepatic glycogen in tilapia (Oreochromis niloticus) (28). In this study, the hepatic glycogen of mandarin fish also decreased at 2 and $4 \mathrm{~d}$ after IP of LepB in appropriate doses. The difference in response to leptin in hepatic glycogen between fish and mammals prompted us to further detect the change in mRNA abundance of the key genes which regulated the rate of hepatic glycogen production. As expected, LepB administration modified the hepatic glycogen level through regulating the expressions of gys and pygl in mandarin fish within $4 \mathrm{~d}$ after IP. The delayed response might be secondary to a depressed effect of LepB administration on glucose production, while inherent mechanism remains to be further explored. LepA treatment did not affect hepatic glycogen level due to the unchanged expression of these regulatory genes. In mammals, leptin was claimed to affect food intake regulation and eventually glucose metabolism (44). Therefore, the reduced hepatic glycogen under LepB administration might be attributed to its induced decrease in food intake of mandarin fish.

In addition, although recent studies suggested that fish, especially carnivorous fish, lacked the ability to regulate gluconeogenesis (45-48), the expression of key genes involved in gluconeogenesis in mandarin fish after IP of leptins were decreased as in mammals. In rat, leptin was reported to reduce hepatic glucose production by decreasing the synthesis of the key enzyme of gluconeogenesis (49). In this study, LepA and LepB downregulated the expressions of key gluconeogenic genes ( $p f k l$, pepck, and $g 6 p c$ ), this indicated both mandarin fish leptins could regulate the rate of glucose production.

In recent study on zebrafish, the role for leptin in the regulation of glucose homeostasis was reported to be conserved 
across vertebrates, whereas its role as an adipostatic factor is likely to be a secondary role acquired during the evolution of mammals (15). In mammals, leptin inhibits fat deposition in liver, mainly by promoting the hydrolysis of fat to increase energy consumption $(50,51)$. In this study, except the hepatic triglyceride of mandarin fish after $1 \mathrm{~d}$ IP of LepA and LepB at partial doses, no more impacts of leptins on cholesterol and triglyceride were observed at other time points, which was in parallel with the changes in expression levels of key genes involved in triglyceride synthesis and hydrolysis. Both LepA and LepB enhanced the triglyceride level at $1 \mathrm{~d}$ after IP, paralleling with the decreased expression of atgl induced by LepA while the increased expression of acc induced by LepB. This result was consistent with the study of Baltzegar et al. (28) which observed a significant increase in hepatic triglyceride within a short period $(6 \mathrm{~h})$ after injected tilapia with human leptin with no significant effect after $24 \mathrm{~h}$. Moreover, the discrepancy of hepatic triglyceride in fish and mammals in response to leptin administration might be due to the different secretory organ of leptin. Unlike in mammals, in which the adipose tissue is the primary site for leptin synthesis, in fish leptin it was reported to be mainly expressed in the liver $(7,9)$.

In summary, LepB of mandarin fish presented an obvious effect of inhibiting food intake after acute IP administration through modifying the expressions of hypothalamic orexigenic genes, while LepA had no significant effect on the food intake of mandarin fish. In addition, acute LepB administration modified the hepatic glycogen level through regulating the expressions of gys and pygl in mandarin fish until $4 \mathrm{~d}$, while the LepA did not affect the hepatic glycogen level, probably because it failed to change the expression of these regulatory genes. Moreover, LepA and LepB downregulated the expressions of key gluconeogenic genes ( $p f k l$, pepck, and $g 6 p c$ ), which suggested both mandarin fish leptins had the ability to regulate the rate of glucose production.

\section{REFERENCES}

1. Pan WW, Myers MG. Leptin and the maintenance of elevated body weight. Nat Rev Neurosci. (2018) 19:95-105. doi: 10.1038/nrn.2017.168

2. Friedman JM. Leptin and the endocrine control of energy balance. Nat Metab. (2019) 1:754-64. doi: 10.1038/s42255-019-0095-y

3. Considine RV, Sinha MK, Heiman ML, Kriauciunas A, Stephens TW, Nyce MR, et al. Serum immunoreactive-leptin concentrations in normal-weight and obese humans. $N$ Engl J Med. (1996) 334:292-5. doi: 10.1056/NEJM199602013340503

4. Ahima RS, Osei SY. Leptin signaling. Physiol Behav. (2004) 81:22341. doi: 10.1016/j.physbeh.2004.02.014

5. Schwartz MW, Niswender KD. Adiposity signaling and biological defense against weight gain: absence of protection or central hormone resistance? J Clin Endocr Metab. (2004) 89:5889-97. doi: 10.1210/jc.20 04-0906

6. Taylor JS, Braasch I, Frickey T, Meyer A, van de Peer Y. Genome duplication, a trait shared by 22,000 species of ray-finned fish. Genome Res. (2003) 13:382-90. doi: 10.1101/gr.640303

7. Gorissen M, Bernier NJ, Nabuurs SB, Flik G, Huising MO. Two divergent leptin paralogues in zebrafish (Danio rerio) that originate early in teleostean evolution. J Endocrinol. (2009) 201:329-39. doi: 10.1677/JOE-0 9-0034
However, leptins presented a limited effect on lipid metabolism as they only enhanced the triglyceride level by modifying the expression of atgl or acc just for $1 \mathrm{~d}$ after IP. Therefore, LepB played an important role in food intake regulation and glucose metabolism, while LepA played a limited role in gluconeogenesis and lipid metabolism.

\section{DATA AVAILABILITY STATEMENT}

All datasets generated for this study are included in the article/supplementary material.

\section{ETHICS STATEMENT}

The animal study was reviewed and approved by the ethical committee of Huazhong Agricultural University.

\section{AUTHOR CONTRIBUTIONS}

$\mathrm{X}-\mathrm{CY}$ conceived the study, participated in the design of the study, carried out the laboratory work, participated in data analysis, and wrote the first draft of the manuscript. X-FL designed the study and contributed to the final version. W-JC and A-XL carried out the laboratory work and assisted with data interpretation. $\mathrm{DH}$ collected the source animals and assisted with establishing the experimental treatments. SH participated in data analysis. All authors have read and approved the manuscript.

\section{FUNDING}

This work was financially supported by National Key R\&D Program of China (2018YFD0900400) and the National Natural Science Foundation of China (31772822).
8. Copeland DL, Duff RJ, Liu Q, Prokop J, Londraville RL. Leptin in teleost fishes: an argument for comparative study. Front Physiol. (2011) 2:26. doi: 10.3389/fphys.2011.00026

9. Huising MO, Geven EJW, Kruiswijk CP, Nabuurs SB, Stolte EH, Spanings FAT, et al. Increased leptin expression in common carp (Cyprinus carpio) after food intake but not after fasting or feeding to satiation. Endocrinology. (2006) 147:5786-97. doi: 10.1210/en.2006-0824

10. Ronnestad I, Nilsen TO, Murashita K, Angotzi AR, Moen AGG, Stefansson $\mathrm{SO}$, et al. Leptin and leptin receptor genes in Atlantic salmon: cloning, phylogeny, tissue distribution and expression correlated to long-term feeding status. Gen Comp Endocr. (2010) 168:55-70. doi: 10.1016/j.ygcen.201 0.04 .010

11. Angotzi AR, Stefansson SO, Nilsen TO, Rathore RM, Ronnestad I. Molecular cloning and genomic characterization of novel Leptin-like genes in salmonids provide new insight into the evolution of the Leptin gene family. Gen Comp Endocr. (2013) 187:48-59. doi: 10.1016/j.ygcen.201 3.03.022

12. Kurokawa T, Murashita K. Genomic characterization of multiple leptin genes and a leptin receptor gene in the Japanese medaka, Oryzias latipes. Gen Comp Endocr. (2009) 161:229-37. doi: 10.1016/j.ygcen.200 9.01 .008

13. Zhang HX, Chen HP, Zhang Y, Li SS, Lu DQ, Zhang HF, et al. Molecular cloning, characterization and expression profiles of multiple leptin genes and 
a leptin receptor gene in orange-spotted grouper (Epinephelus coioides). Gen Comp Endocr. (2013) 181:295-305. doi: 10.1016/j.ygcen.2012.09.008

14. Tinoco AB, Nisembaum LG, Isorna E, Delgado MJ, de Pedro N. Leptins and leptin receptor expression in the goldfish (Carassius auratus). Regulation by food intake and fasting/overfeeding conditions. Peptides. (2012) 34:32935. doi: 10.1016/j.peptides.2012.02.001

15. Michel M, Page-McCaw PS, Chen W, Cone RD. Leptin signaling regulates glucose homeostasis, but not adipostasis, in the zebrafish. P Natl Acad Sci. (2016) 113:3084-9. doi: 10.1073/pnas.1513 212113

16. Chen T, Chen S, Ren CH, Hu CQ, Tang DS, Yan AF. Two isoforms of leptin in the white-clouds mountain minnow (Tanichthys albonubes): differential regulation by estrogen despite similar response to fasting. Gen Comp Endocr. (2016) 225:174-84. doi: 10.1016/j.ygcen.201 5.08 .002

17. de Pedro N, Martinez-Alvarez R, Delgado MJ. Acute and chronic leptin reduces food intake and body weight in goldfish (Carassius auratus). $J$ Endocrinol. (2006) 188:513-20. doi: 10.1677/joe. 1.06349

18. Baker DM, Larsen DA, Swanson P, Dickhoff WW. Long-term peripheral treatment of immature coho salmon (Oncorhynchus kisutch) with human leptin has no clear physiologic effect. Gen Comp Endocr. (2000) 118:1348. doi: 10.1006/gcen.1999.7450

19. Londraville RL, Duvall CS. Murine leptin injections increase intracellular fatty acid-binding protein in green sunfish (Lepomis cyanellus). Gen Comp Endocr. (2002) 129:56-62. doi: 10.1016/S0016-6480(02) 00510-5

20. He S, Liang XF, Sun J, Li L, Yu Y, Huang W, et al. Insights into food preference in hybrid F1 of Siniperca chuatsi (female) x Siniperca scherzeri (male) mandarin fish through transcriptome analysis. BMC Genomics. (2013) 14:601. doi: 10.1186/1471-2164-14-601

21. Liang XF, Kiu JK, Huang BY. The role of sense organs in the feeding behaviour of Chinese perch. J Fish Biol. (1998) 52:1058-67. doi: 10.1111/j.1095-8649.1998.tb00603.x

22. Chiang L. On the biology of mandarinfish, Siniperca chuatsi, of Liangtze lake. Acta Hydrobiol Sin. (1959) 3:365-85.

23. Yuan XC, Li AX, Liang XF, Huang W, Song Y, He S, et al. Leptin expression in mandarin fish Siniperca chuatsi (Basilewsky): Regulation by postprandial and short-term fasting treatment. Comp Biochem Phys A. (2016) 194:818. doi: 10.1016/j.cbpa.2016.01.014

24. Volkoff H, Eykelbosh AJ, Peter RE. Role of leptin in the control of feeding of goldfish Carassius auratus: interactions with cholecystokinin, neuropeptide $\mathrm{Y}$ and orexin A, and modulation by fasting. Brain Res. (2003) 972:90109. doi: 10.1016/S0006-8993(03)02507-1

25. Murashita K, Uji S, Yamamoto T, Ronnestad I, Kurokawa T. Production of recombinant leptin and its effects on food intake in rainbow trout (Oncorhynchus mykiss). Comp Biochem Phys B. (2008) 150:377-84. doi: 10.1016/j.cbpb.2008.04.007

26. Li GG, Liang XF, Xie QL, Li GZ, Yu Y, Lai KS. Gene structure, recombinant expression and functional characterization of grass carp leptin. Gen Comp Endocr. (2010) 166:117-27. doi: 10.1016/j.ygcen.200 9.10.009

27. Song YF, Wu K, Tan XY, Zhang LH, Zhuo MQ, Pan YX, et al. Effects of recombinant human leptin administration on hepatic lipid metabolism in yellow catfish Pelteobagrus fulvidraco: in vivo and in vitro studies. Gen Comp Endocrinol. (2015) 212:92-9. doi: 10.1016/j.ygcen.201 5.01.022

28. Baltzegar DA, Reading BJ, Douros JD, Borski RJ. Role for leptin in promoting glucose mobilization during acute hyperosmotic stress in teleost fishes. J Endocrinol. (2014) 220:61-72. doi: 10.1530/JOE-1 3-0292

29. Vandesompele J, de Preter K, Pattyn F, Poppe B, van Roy N, de Paepe A, et al. Accurate normalization of real-time quantitative RT-PCR data by geometric averaging of multiple internal control genes. Genome Biol. (2002) 3:30. doi: 10.1186/gb-2002-3-7-research0034

30. Livak KJ, Schmittgen TD. Analysis of relative gene expression data using real-time quantitative PCR and the $2^{- \text {DDCT }}$ method. Methods. (2001) 25:4028. doi: $10.1006 /$ meth. 2001.1262
31. Liu CZ, He AY, Ning LJ, Luo Y, Li DL, Zhang ML, et al. Leptin selectively regulates nutrients metabolism in Nile tilapia fed on high carbohydrate or high fat diets. Front Endocrinol. (2018) 9:574. doi: 10.3389/fendo.201 8.00574

32. Volkoff H. Fish as models for understanding the vertebrate endocrine regulation of feeding and weight. Mol Cell Endocrinol. (2019) 497:110437. doi: 10.1016/j.mce.2019.04.017

33. Londraville RL, Macotela Y, Duff RJ, Easterling MR, Liu Q, Crespi EJ. Comparative endocrinology of leptin: assessing function in a phylogenetic context. Gen Comp Endocr. (2014) 203:146-57. doi: 10.1016/j.ygcen.2014.02.002

34. Stanley S, Wynne K, McGowan B, Bloom S. Hormonal regulation of food intake. Physiol Rev. (2005) 85:1131-58. doi: 10.1152/physrev.0001 5.2004

35. Wynne K, Stanley S, McGowan B, Bloom S. Appetite control. J Endocrinol. (2005) 184:291-318. doi: 10.1677/joe. 1.05866

36. Volkoff H, Canosa LF, Unniappan S, Cerda-Reverter JM, Bernier NJ, Kelly SP, et al. Neuropeptides and the control of food intake in fish. Gen Comp Endocr. (2005) 142:3-19. doi: 10.1016/j.ygcen.2004 .11 .001

37. Zhou Y, Liang XF, Yuan XC, Li J, He Y, Fang L, et al. Neuropeptide Y stimulates food intake and regulates metabolism in grass carp, Ctenopharyngodon idellus. Aquaculture. (2013) 380:52-61. doi: 10.1016/j.aquaculture.2012.11.033

38. Chu SC, Chen PN, Chen JR, Yu CH, Hsieh YS, Kuo DY. Role of hypothalamic leptin-LepRb signaling in NPY-CART-mediated appetite suppression in amphetamine-treated rats. Horm Behav. (2018) 98:17382. doi: 10.1016/j.yhbeh.2017.12.019

39. Schwartz MW, Woods SC, Porte D, Seeley RJ, Baskin DG. Central nervous system control of food intake. Nature. (2000) 404:661-71. doi: 10.1038/35007534

40. Peterson BC, Waldbieser GC, Riley LG, Upton KR, Kobayashi Y, Small BC. Pre- and postprandial changes in orexigenic and anorexigenic factors in channel catfish (Ictalurus punctatus). Gen Comp Endocr. (2012) 176:2319. doi: 10.1016/j.ygcen.2012.01.022

41. Haissaguerre M, Ferriere A, Simon V, Saucisse N, Dupuy N, Andre C, et al. mTORC1-dependent increase in oxidative metabolism in POMC neurons regulates food intake and action of leptin. Mol Metab. (2018) 12:98106. doi: 10.1016/j.molmet.2018.04.002

42. Margetic S, Gazzola C, Pegg GG, Hill RA. Leptin: a review of its peripheral actions and interactions. Int J Obesity. (2002) 26:1407-33. doi: 10.1038/sj.ijo.0802142

43. Aguilar AJ, Conde-Sieira M, Polakof S, Miguez JM, Soengas JL. Central leptin treatment modulates brain glucosensing function and peripheral energy metabolism of rainbow trout. Peptides. (2010) 31:1044-54. doi: 10.1016/j.peptides.2010.02.026

44. Hussain Z, Khan JA. Food intake regulation by leptin: Mechanisms mediating gluconeogenesis and energy expenditure. Asian Pac J Trop Med. (2017) 10:940-4. doi: 10.1016/j.apjtm.2017.09.003

45. Panserat S, Plagnes-Juan E, Kaushik S. Nutritional regulation and tissue specificity of gene expression for proteins involved in hepatic glucose metabolism in rainbow trout (Oncorhynchus mykiss). J Exp Biol. (2001) 204:2351-60. Available online at: https://archimer.ifremer.fr/doc/ 2001/publication-415.pdf

46. Panserat S, Plagnes-Juan E, Kaushik S. Gluconeogenic enzyme gene expression is decreased by dietary carbohydrates in common carp (Cyprinus carpio) and gilthead seabream (Sparus aurata). BBA Gene Struct Expr. (2002) 1579:35-42. doi: 10.1016/S0167-4781(02)00501-8

47. Marandel L, Seiliez I, Veron V, Skiba-Cassy S, Panserat S. New insights into the nutritional regulation of gluconeogenesis in carnivorous rainbow trout (Oncorhynchus mykiss): a gene duplication trail. Physiol Genom. (2015) 47:253-63. doi: 10.1152/physiolgenomics.0002 6.2015

48. Marandel L, Panserat S, Plagnes-Juan E, Arbenoits E, Soengas JL, Bobe J. Evolutionary history of glucose-6-phosphatase encoding genes in vertebrate lineages: towards a better understanding of the functions of multiple duplicates. BMC Genom. (2017) 18:342. doi: 10.1186/s12864-017$3727-1$ 
49. Anderwald C, Muller G, Koca G, Furnsinn C, Waldhausl W, Roden M. Short-term leptin-dependent inhibition of hepatic gluconeogenesis is mediated by insulin receptor substrate-2. Mol Endocrinol. (2002) 16:161228. doi: 10.1210/mend.16.7.0867

50. Fruhbeck G, Aguado M, Martinez JA. In vitro lipolytic effect of leptin on mouse adipocytes: evidence for a possible autocrine/paracrine role of leptin. Biochem Biophys Res Commun. (1997) 240:5904. doi: 10.1006/bbrc.1997.7716

51. Siegrist-Kaiser CA, Pauli V, Juge-Aubry CE, Boss O, Pernin A, Chin WW, et al. Direct effects of leptin on brown and white adipose tissue. J Clin Invest. (1997) 100:2858-64. doi: 10.1172/JCI119834
Conflict of Interest: The authors declare that the research was conducted in the absence of any commercial or financial relationships that could be construed as a potential conflict of interest.

Copyright (c) 2020 Yuan, Liang, Cai, Li, Huang and He. This is an open-access article distributed under the terms of the Creative Commons Attribution License (CC $B Y)$. The use, distribution or reproduction in other forums is permitted, provided the original author(s) and the copyright owner(s) are credited and that the original publication in this journal is cited, in accordance with accepted academic practice. No use, distribution or reproduction is permitted which does not comply with these terms. 